\title{
The Interpretative Methods of International Law: What Are They, and Why Use Them?
}

\begin{abstract}
[I]nterpretation is not a mere technical device, but a political matter of the utmost importance: it may eventually depend on which interpretative method is applied whether a state (or any other actor, for that matter) can be accused of an internationally wrongful act, or whether it will be regarded as having stayed faithful to its commitments. ${ }^{1177}$
\end{abstract}

\section{Introduction}

In Chapter 5 (supra), I have stressed that interpretative methods guide domestic and international legal practice, and that there are good reasons for requiring judges to abide by them. I have not yet examined the specific interpretative methods of international law, and the reasons for using these methods in particular.

The present chapter is devoted to these issues. These questions matter because States (including courts) must know what methods the law requires them to apply, and because the addressees of legal decisions must know by which standards States and their authorities should be held accountable. Moreover, it is essential to grasp the importance of each and every method, and the relationship between all of them.

In this chapter, I claim that States, to honor their international obligations, must use the interpretative methods of international law, namely textual, systematic, teleological, and historical interpretation. Trivial and uncontroversial as this point may seem, it is too often discarded or overlooked by scholars and

1177 Klabbers, 'International Legal Histories: The Declining Importance of Travaux Préparatoires in Treaty Interpretation?' (n 994) 274. 
courts. This neglect of interpretative methods jeopardizes the legality and the predictability, clarity, and consistency of judicial reasoning.

My goal, in this chapter, is two-fold. First, I identify the interpretative methods that must be used to interpret international law. These methods, I argue, apply to all sources of international law. Second, I explain why there are good reasons ${ }^{1178}$ for using these methods. Interpretative methods should not be neglected, even if this is often the case in practice.

I do not argue for the priority of one method over others (ie, for the validity of one particular normative interpretative theory, supra, Chapter 2, 5.1). Karl Llewellyn, by noting that every 'parry' comes with a 'thrust', has shown that every interpretative canon can be countered by another contradictory one. ${ }^{1179}$ Methods point in different directions, and all these directions, I claim, deserve attention. My endeavor thereby differs from that of scholars who have put forward a full-fledged theory of interpretation of international law. ${ }^{1180}$

\section{The Interpretative Methods of International Law}

To obtain a better understanding of the methods required by international law, it is useful to rely on insights gained in domestic law. Contrary to what is often assumed, the interpretative methods of domestic and international law share the same traits (supra, Chapter $5,3.3$ ). What differs between domestic and international law are some features of their lawmaking processes. ${ }^{1181}$ These differences may have some implications for their respective interpretative methods, ${ }^{1182}$ but the basic characteristics of these methods are the same.

To identify the interpretative methods of international law, I consult the VCLT and the ILC's draft conclusions on identification of CIL. ${ }^{1183}$ One could

1178 I will not examine whether the use of these methods makes an interpretation legitimate all things considered. As previously mentioned, this question is beyond the scope of my study (supra, Introduction, section 3). However, some of the claims I make in this chapter do provide elements for such a theory of legitimacy.

1179 Llewellyn (n 1138). Sean D. Murphy has transposed Llewellyn's theory to international law: Murphy (n 163) $16 \mathrm{f}$.

118 o One example is the theory developed by Letsas ( $\mathrm{n} 79$ ).

$1181 \mathrm{Eg}$ the fact that international lawmaking requires the involvement of at least two States.

1182 Eg in treaty interpretation, a broader definition of context encompassing, inter alia, other international legal acts and the practices of the treaty parties. See art. 31(3)(b) and (c) VCLT.

1183 ILC, 'Draft Conclusions on Identification of Customary International Law, With Commentaries' (n 891). 
argue that the ILC's mandate consists not only in the codification, but also in the 'progressive development' of international law. ${ }^{1184}$ One could also contend that the customary status of the methods of the VCLT is controversial. Thus, these two instruments might arguably not reflect customary methods or serve as useful interpretative guides. However, I submit that there are good reasons for relying on them.

First, both documents seem the most obvious starting point for an analysis of the interpretative methods of international law. The customary status of the VCLT's methods was, indeed, controversial at the time the Convention was adopted, ${ }^{1185}$ and the ICJ affirmed it only gradually. ${ }^{1186}$ In the early 1930s, scholars considered that treaty interpretation was 'among the most confused subjects in international law'.1187 However, at the time of their drafting, the relevant provisions of the VCLT triggered few comments by States, who mainly disagreed about the weight to be given to these methods, ${ }_{1188}^{11}$ and hence about normative interpretative theories (supra, Chapter 2, 5.1). Admittedly, art. $3_{1} \mathrm{f}$ VCLT catalyzed the formation of customary law on treaty interpretation, which was still embryonic at that time. ${ }^{1189}$ Yet today, and for at least the past three decades, an overwhelming majority ${ }^{1190}$ of States, domestic and international courts (including the ICJ), and international lawyers deem the VCLT a reflection of customary methods of treaty interpretation. ${ }^{1191}$

As to the ILC's draft conclusions on identification of CIL, which were finalized in 2018, one could argue that it is too early to consider them a reliable reflection of customary methods. The draft conclusions can be criticized for

1184 Art. 1(1) ILC Statute.

1185 Gardiner (n 359) 76. See also Yves Le Bouthillier, 'Article 32' in Olivier Corten and Pierre Klein (eds), The Vienna Conventions on the Law of Treaties: A Commentary, Vol I (Oxford University Press 2011) $843 \mathrm{f}$.

1186 Gardiner (n 359) $13 \mathrm{ff}$.

1187 Yi-Ting Chang, The Interpretation of Treaties by Judicial Tribunals (Columbia University Press 1933) 19, cited by 'Article 19. Interpretation of Treaties' (n 121) 939.

1188 Sorel and Boré-Eveno (n 1044) $815 \mathrm{f}$.

1189 See ibid 8o6. See also ibid $810 \mathrm{f}$.

1190 By contrast, the CJEU is more reluctant to do so, see Sorel and Boré-Eveno (n 1044) 822.

1191 Gardiner 146 ff; Jean d'Aspremont, 'The Systemic Integration of International Law by Domestic Courts: Domestic Judges as Architects of the Consistency of the International Legal Order' in Ole Kristian Fauchald and André Nollkaemper (eds), The Practice of International and National Courts and the (De-)Fragmentation of International Law (Hart Publishing 2012) 151. See also the references to the ICJ's case law on art. 31 VCLT in Petersen (n 73) n 53. Some scholars press for a redrafting of the VCLT's interpretative provisions: Chang-fa Lo, Treaty Interpretation Under the Vienna Convention on the Law of Treaties: A New Round of Codification (Springer 2017). 
predominantly drawing on the practice of the ICJ and other international courts. Moreover, some scholars deem them minimalistic and removed from practical considerations. ${ }^{1192}$ However, there are good reasons for relying on the draft conclusions as a starting point: they have not met with fundamental criticism on the part of States; ${ }^{1193}$ the ILC endeavored to collect information from States regarding their practice; ${ }^{1194}$ and the conclusions are the most recent statement of the methods of identification of customary law elaborated in an inclusive, public, and international forum.

A second reason for relying on these two resources is, of course, that ascertaining State practice and opinio juris from scratch with regard to the interpretative methods of treaty law, CIL, and general principles is an extraordinarily laborious task that is beyond the scope of this study. In addition to these two documents, I draw upon the comments made by the governments of the States involved in their drafting process ${ }^{1195}$ (except for documents unavailable in French or English) or by international or regional organizations such as the AALCO. ${ }^{1196}$ I also build on the efforts of other bodies than the ILC to clarify the interpretative methods of treaty law and CIL, ${ }^{1197}$ and on international legal scholarship. When relying on these resources, it is essential to focus, whenever possible, on expressions of State practice and opinio juris, since norms about mandatory interpretative methods are customary norms.

1192 Stefan Talmon, 'Determining Customary International Law: The ICJ's Methodology and the Idyllic World of the ILC' (EJIL: Talk!, 2015) < www.ejiltalk.org/determining-customaryinternational-law-the-icjs-methodology-and-the-idyllic-world-of-the-ilc $>$.

1193 See the comments submitted by governments at <legal.un.org/ilc/guide/1_13.shtml >. As indicated by Noora Arajärvi, governmental statements made in the UN General Assembly can be retrieved on <papersmart.unmeetings.org>: Arajärvi (n 37) 19, footnote 49. See however the forceful critique of BS Chimni, 'Customary International Law: A Third World Perspective' (2018) 112 American Journal of International Law 1.

1194 ILC, 'Report of the International Law Commission, Sixty-Fourth Session (7 May-1 June and 2 July-3 August 2012)' (2012) UN Doc A/67/10 8. The document forming the basis for Switzerland's submission is Besson and Ammann (n 6o).

1195 These comments are included in the ILC's analytical guides on the law of treaties ('Comments by Governments', <legal.un.org/ilc/guide/1_1.shtml>, especially <legal. un.org/docs/?path=../ilc/documentation/english/a_cn4_182.pdf\&lang=EF $>$ ) and on the identification of CIL ('Comments by Governments', <legal.un.org/ilc/guide/1_13.shtml>).

1196 Sienho (n 960); SufianJusoh, 'A Dialogue Between UN and AALCo Experts on Identification of Customary International Law' (2016) 15 Chinese Journal of International Law 1.

1197 On the law of treaties, see Institut de droit international, 'Interprétation des traités' (1956) <www.idi-iil.org/idiF/resolutionsF/1956_grena_o2_fr.pdf>; 'Harvard Draft Convention on the Law of Treaties' (1935) 29 American Journal of International Law 657. On CIL, see ILA Committee on Formation of Customary (General) International Law (n 886). 
It is important to concede that these means cannot replace such a comprehensive survey of State practice and opiniojuris.

Although I start from the VCLT and from the ILC's work, the methods these documents identify should not be taken for granted. ${ }^{1198}$ The fact that most States and other actors deem a method customary does not prove its customary status. Both documents should therefore be approached critically, contrary to what is often the case in scholarship. In this chapter, I will examine whether there are compelling reasons to doubt these methods' customary character, but also to require States to use these methods.

The interpretative methods of international law fall into four categories: textual (2.1), systematic (or contextual) (2.2), purposive (or teleological) (2.3), and historical (2.4). ${ }^{1199}$ They are congruent with the four methods of statutory interpretation identified by Friedrich Karl von Savigny. Scholars have noted that Savigny's methods 'can be observed in every national methodology', ${ }^{1200}$ even if States' terminology to describe them is inconsistent (especially between common law and civil law jurisdictions). I analyze the relationship between the four methods in the last section of this chapter (2.5).

One important claim that I make in this chapter - and which is in disagreement with mainstream scholarship - is that the aforementioned four methods

1198 This is what the great bulk of international legal scholarship seems to do, at least regarding art. $31 \mathrm{f}$ VCLT. For an iconoclast position, see d'Aspremont, 'The International Court of Justice, the Whales, and the Blurring of the Lines Between Sources and Interpretation' (n 224) 1030. See also Klabbers, 'Virtuous Interpretation' (n 93). Klabbers seems to suggest that the VCLT's methods are not customary (i) because interpretation is not governed by rules, which conflates the question of the source of interpretative methods with the type of obligations these methods create; (ii) because there were proponents of different approaches to interpretation before the VCLT was adopted, an argument that disregards the distinction between interpretative methods and normative interpretative theories (supra, Chapter 2, 5.1); (iii) because in international legal practice, no sanction is attached to the violation of interpretative methods. Yet methods are dutyimposing secondary norms, regardless of how the law addresses departures from them. Moreover, the customary character of a norm does not hinge on whether this norm is assorted with a sanction. Klabber's third argument also seems to contradict his own statement in Klabbers, 'International Legal Histories: The Declining Importance of Travaux Préparatoires in Treaty Interpretation?' (n 994) 274.

1199 See also Schlütter (n 179) 97.

1200 Larry A DiMatteo and André Janssen, 'Interpretive Methodologies in the Interpretation of the CISG' in Larry A DiMatteo (ed), International Sales Law: A Global Challenge (Cambridge University Press 2014) 83. See also Stefan Vogenauer, Die Auslegung von Gesetzen in England und auf dem Kontinent: eine vergleichende Untersuchung der Rechtsprechung und ihrer historischen Grundlagen (Mohr Siebeck 2001). 
govern the interpretation of treaties, but also of $\mathrm{CIL}^{1201}$ and general principles of international law. Analyses of the methods of identification of CIL largely focus on State practice and opinio juris. ${ }^{1202}$ These elements are not methods, however, but constitutive elements of custom that require to be ascertained and doing so requires using specific methods. The four methods also apply to general principles. The few rulings and scholarly writings available have highlighted the importance of (careful) analogical reasoning ${ }^{1203}$ and comparative ${ }^{1204}$ reasoning for the purposes of ascertaining general principles, but they have rarely talked about interpretative methods. Given the scarce practice pertaining to general principles of international law, my comments on them will primarily draw from scholarly writings.

Before moving on to the analysis, some final caveats are in order. First, by analyzing the aforementioned four methods, I do not exclude the existence (present or future) of other (or more specific) customary interpretative methods. However, the four methods highlighted in this chapter deserve particular emphasis. The four methods of art. $31 \mathrm{f} \mathrm{VCLT}$ are the least disputed interpretative methods in international law. Of course, this agreement in principle does not preclude disagreements about the proper application of these methods, nor does it rule out inconsistencies and mistakes in their application, or even occasional departures from them. Importantly, the four methods are broad

1201 See (with many practical examples) Merkouris (n 199); Merkouris (n 231). My position on the applicability of the VCLT's methods to CIL somewhat differs from that of Merkouris, who argues that the VCLT's methods apply to CIL once this custom has been ascertained. Contra Schlütter (n 179) 9o. See also ICJ, case concerning Military and Paramilitary Activities in and Against Nicaragua (Nicaragua v. United States), merits, ICJ Reports 1986, 14, at 95, para 178. However, the Court's statement that treaty law and customary law 'are distinguishable by reference to the methods of interpretation and application' points to the 'institutions or mechanisms [established] to ensure implementation of the rule' rather than to differences in terms of interpretative methods as understood in this book.

1202 For such a finding, see Merkouris (n 231). For a recent example, see ILC, 'Draft Conclusions on Identification of Customary International Law, With Commentaries' (n 891). See also Niels Petersen, 'Customary Law Without Custom? Rules, Principles, and the Role of State Practice in International Norm Creation' (2007) 23 American University International Law Review 275; Arajärvi (n 37).

1203 Besson, 'General Principles in International Law: Whose Principles?' (n 935) 36; Jaye Ellis, 'General Principles and Comparative Law' (2011) 22 European Journal of International Law 949, 958 f; Thirlway (n 1156) 97 f; Weiss (n 936) 407 f.

1204 Besson, 'General Principles in International Law: Whose Principles?' (n 935) 36; Ellis (n 1203) 955 ff; Thirlway (n 1156) 95; Stephan W Schill, 'General Principles of Law and International Investment Law' in Tarcisio Gazzini and Eric De Brabandere (eds), International Investment Law: The Sources of Rights and Obligations (Brill/Nijhoff 2012); Weiss (n 936) 407. 
enough to encompass a number of more specific ones. Evaluating these methods can hence yield useful insights about these more specific methods as well.

A second caveat is that I argue from the assumption that there are general interpretative methods, namely methods that apply to all international legal acts regardless of their subject matter. Some authors argue that selected substantive regimes of international law are governed by 'special' or 'specialized' methods that depart from the 'general' interpretative methods (eg the methods of the VCLT). ${ }^{1205}$ Yet what varies between these so-called 'general' versus 'special' methods is not the method per se, but the type of interpretative material that is available in different regimes of international law. This point also applies to $\mathrm{CIL}^{1206}$ and to general principles of international law.

Third, some topics are excluded from this chapter. I do not address States' duty to interpret treaties 'in good faith', ${ }^{1207}$ which is an axiological interpretative principle (supra, Chapter 2, 5.2) rather than an interpretative method. Nor do I focus on the interpretation of multilingual treaties (art. 33 VCLT), which is not a method, but a rule addressing specific difficulties liable to arise in connection with textual interpretation.

\section{Textual Interpretation}

2.1.1

Domestic Law

Textual (or literal) interpretation is the use of the ordinary meaning of written acts to ascertain the law. What does domestic legal theory tell us about this method? Is it legally required in domestic legal orders? If so, are there good reasons for requiring its use?

Few lawyers would dispute that the text is the starting point to ascertain the meaning of written laws (eg statutes). In fact, it is difficult to imagine how they could, since the text is the most straightforward feature of written law. Textual interpretation is the first method in Savigny's 'four elements' doctrine and the first method courts refer to. ${ }^{1208}$ Textual interpretation, called the 'plain

1205 Catherine Brölmann, 'Specialized Rules of Treaty Interpretation: International Organizations' in Duncan Hollis (ed), The Oxford Guide to Treaties (Oxford University Press 2012). Contra Eirik Bjorge, 'Different Regimes, Different Methods of Interpretation?' in Mads Andenas and Eirik Bjorge (eds), The Evolutionary Interpretation of Treaties (Cambridge University Press 2014).

1206 Wood (n 14) 9. See also Wood's observation that the different regimes of CIL are interconnected: ILC, 'First Report on Formation and Evidence of Customary International Law by Special Rapporteur Sir Michael Wood' (n 185) 7 f, para 19; ILC, 'Second Report on Identification of Customary International Law by Special Rapporteur Sir Michael Wood' (n 578 ) $11 \mathrm{ff}$, para 28.

1207 Art. 31(1) VCLT.

1208 Eg BGE 141 II 436, at 4.1; BGE 140 II 415, at 5.4. 
meaning rule' in us law, and the 'literal rule' in English law, is also a standard method in common law jurisdictions. ${ }^{1209}$

Hence, some might even argue that textual interpretation is on a different level than other methods, which are subordinated to it. Other methods, one might claim, are only ways of interpreting wording: since we are always looking at words, textual interpretation is not a self-standing method.

It is true that interpreters, because they are embedded in a communicative practice, cannot help but look at ordinary meaning. Yet textual interpretation is an autonomous method, even if other methods may require textual interpretation as well, and vice versa. The focus on ordinary meaning, as banal (and central) as it may seem, is a distinctive way of ascertaining the law. Moreover, in legal interpretation, the interpretandum is not the text itself, but a social fact that is (in most cases, but not always) $)^{1210}$ expressed in words.

Textual interpretation is warranted on several grounds. First, it limits the discretion of decision-makers by forcing them to consider the wording adopted by the legislature. Savigny for instance deemed the text a mediator between the legislature and its subjects. ${ }^{1211}$ Second, the text is easily identifiable and accessible, even if there can be reasonable disagreement about its meaning. Ascertaining the purpose, legislative history, and context of legal acts may require extensive research; the text is usually straightforward.

Textual interpretation can be criticized on various counts. First, it is only helpful if the wording is determinate. Some even contest the concept of 'plain', 'ordinary meaning'; in their view, texts are never determinate, and their meaning, like a chameleon, changes with the context. ${ }^{1212}$ Undoubtedly, we often disagree about the meaning of texts, the ambiguity of which can be deliberate or fortuitous. Yet legal texts are not radically indeterminate. They are embedded in our social communicative practices. As Aharon Barak puts it, '[w]ords do have meaning. A cigarette is not an elephant'.1213

\footnotetext{
1209 See the so-called 'semantic' and 'syntactic canons' described by Antonin Scalia and Bryan A Garner, Reading Law: The Interpretation of Legal Texts (Thomson/West 2012).

$1210 \mathrm{CIL}$, for instance, can be expressed in non-verbal acts. Of course, to interpret these acts, the interpreter is likely to use written materials of some sort, but the interpretandum itself is not expressed in words.

1211 von Savigny (n 761$) 213$.

1212 Derrida, 'Signature, événement, contexte' (n 1145). See also Amstutz (n 79o). Stanley Fish argues that the meaning of texts differs from one interpretive community to another. See Fish, Is There a Text in This Class? The Authority of Interpretive Communities (n 982) 5 .

1213 Aharon Barak, 'Hermeneutics and Constitutional Interpretation' (1992) 14 Cardozo Law Review 767,767 .
} 
A second objection is that textual interpretation only applies to written law. Yet this disregards that unwritten law is often ascertained via verbal acts, eg auxiliary means.

Third, one might observe that there are different methods for ascertaining the ordinary meaning of texts. ${ }^{1214}$ Hence, textual interpretation arguably creates more difficulties than it purports to solve. True, methods do not state how they should be employed, and textual interpretation, like any method, can be conducted in light of other methods. Yet this does not make textual interpretation useless. Any approach to textual interpretation is a normative position that must be argued for. Methods are not interpretative theories (supra, Chapter 2, 5.1). We cannot expect them to solve problems they cannot tackle.

Fourth, textual interpretation can be (and is often) criticized when it disregards other interpretative methods. Yet the fact that one-sided, 'textualist' approaches are misguided does not lead to the conclusion that textual interpretation is flawed. Using textual interpretation does not require endorsing originalism, for instance (supra, Chapter 2, 5.1).

To conclude, there are good reasons for using textual interpretation in full awareness of its strengths and weaknesses, together with other methods $(2.2-2.4)$.

\subsubsection{International Law}

Like in domestic law, textual interpretation is so pervasive in international law that doubts about its customary character seem redundant. Textual interpretation is the starting point of treaty interpretation, ${ }^{1215}$ a treaty being, by definition, written. ${ }^{1216}$ The determination of CIL often requires textual interpretation, as State practice and opinio juris are mainly reflected in verbal acts. ${ }^{1217}$ Pursuant to the ILC's draft conclusions, treaties, resolutions of IOs, and

1214 Eg based on the drafters' intention or based on the ordinary meaning of the text at the time of its enactment. These two solutions reflect the distinction some authors draw between two types of originalism, namely intentionalism and textualism, see Letsas (n 79) 6o.

1215 ILC, 'Draft Articles on the Law of Treaties With Commentaries' (n 783) 219 f; Fatima (n 45) 83 f. Textual interpretation is mentioned in art. 31(1) and (4) VCLT.

1216 See art. 2(1)(a) vCLT.

1217 Draft conclusions 6 and 10, ILC, 'Draft Conclusions on Identification of Customary International Law, With Commentaries' (n 891). For a critique: Sienho (n 96o) 385 f. See also Tullio Treves, 'Customary International Law', Max Planck Encyclopedia of Public International Law (Online Edition) (Oxford University Press 2008) <opil.ouplaw.com>. Treves considers that custom cannot be interpreted because interpretation, he alleges, is limited to verbal acts. 
auxiliary means (ie, judicial decisions and scholarship) can all be used to identify custom. ${ }^{1218}$ Similarly, general principles of international law are primarily ascertained based on States' practice of recognition, treaties, custom, ${ }^{1219}$ and auxiliary means.

The practice of treaty interpretation (and, most importantly, the practice of States) ${ }^{1220}$ suggests that textual interpretation is a customary interpretative method. ${ }^{1221}$ Only few analyses and draft conventions on treaty interpretation neglect textual interpretation. ${ }^{122}$ As regards CIL, decision-makers, in the vast majority of cases, rely on verbal, written acts to ascertain it. ${ }^{1223}$ The importance of verbal acts is also reflected in the ILA's work on the issue. ${ }^{1224}$ Such acts are further used in the few international rulings where general principles of international law are ascertained. ${ }^{1225}$

Several reasons explain States' duty to use textual interpretation in international law. First, this method helps respect the intentions of the lawmaking States, ${ }^{1226}$ which the text is presumed to reflect. ${ }^{1227}$ With regard to unwritten

1218 Draft conclusions $11 \mathrm{ff}$ in ILC, 'Draft Conclusions on Identification of Customary International Law, With Commentaries' (n 891). On treaties as means of identification of CIL, see ILA Committee on Formation of Customary (General) International Law (n 886) $43 \mathrm{ff}$.

1219 Ottavio Quirico, 'General Principles of International Criminal Law and Their Relevance to Africa' (2011) 17 African Yearbook of International Law Online 139, $15^{2} \mathrm{ff}$.

1220 On the practice of domestic courts, see Fatima (n 45) 83 f; Waibel, 'Principles of Treaty Interpretation: Developed for and Applied by National Courts?' (n 183) 20.

1221 See also the references to the ICJ's case law in ILC, 'Draft Articles on the Law of Treaties With Commentaries' (n 783) 220 f. See also Institut de droit international, 'Interprétation des traités' (n 1197); Sorel and Boré-Eveno (n 1044) 817 ff.

1222 The Harvard Draft Convention on the Law of Treaties of 1935 does not expressly refer to textual inerpretation qua interpretative method, but mentions it in its commentary, see 'Article 19. Interpretation of Treaties' (n 121) 947 ff. See however ibid 940.

1223 See the comments submitted by the governments of El Salvador, Ireland, the United Kingdom, South Korea, and Finland at the ILC's 66th and 67th session, <legal.un.org/ ilc/guide/1_13.shtml>. On English courts, see Fatima (n 45) 414 ff. On domestic courts in continental Europe, see Jan Wouters, 'Customary International Law Before National Courts: Some Reflections From a Continental European Perspective' (2004) 4 Non-State Actors and International Law 25, $28 \mathrm{ff}$.

1224 ILA Committee on Formation of Customary (General) International Law (n 886) $14 \mathrm{f}$.

1225 ICTY (Trial Chamber I), Prosecutor v. Dražen Erdemović, sentencing judgment, Case No IT-96-22-T, 29 November 1996, at para 27 ff. See also ICTy (Appeals Chamber), Prosecutor v. Dražen Erdemović, judgment, Case No IT-96-22-A, 7 October 1997, joint and separate opinion of Judge McDonald and Judge Vohrah, para $56 \mathrm{ff}$.

1226 Fitzmaurice, 'The Law and Procedure of the International Court of Justice, 1951-4: Treaty Interpretation and Other Treaty Points' (n 1006) 204.

1227 Institut de droit international, 'Interprétation des traités' (n 1197); ILC, 'Draft Articles on the Law of Treaties With Commentaries' (n 783) $220 \mathrm{f}$. 
international law as well, the use of verbal acts secures fidelity to the intentions States have expressed through these acts. Second, the text of international law is its most immediately cognizable feature (except for laws that are not easily accessible).

Of course, textual interpretation also triggers criticism. First, is there a shared ordinary meaning on the international plane? Is resort to dictionary definitions warranted in circumstances of linguistic pluralism? Has there ever been a 'meeting of the minds', ${ }^{1228}$ save for an agreement on wording? Even if the parties' respective intentions are congruent, the text may not reflect their intentions. Yet these critiques fail to show that textual interpretation is misguided. By agreeing on the text, States accept the uncertainties of linguistic communication. Even if they leave room for imprecision and disagreement, texts remain the most practicable way for States to bind themselves.

Second, one could argue that textual interpretation is of no assistance to interpret unwritten international law. This objection is easily rebutted: it neglects the practical importance of verbal statements (and hence of textual interpretation) to ascertain custom and general principles of international law, eg via official statements and auxiliary means.

Third, there are different interpretative approaches to textual interpretation. Even if the parties use the same method, they may disagree about the way of going about it. ${ }^{1229}$ This challenge does not defeat textual interpretation, however. It merely (and rightly) criticizes the endorsement of a specific approach to the text that does not offer compelling arguments in its support.

Lastly, textual interpretation has been criticized for disregarding non-textual features of international law. ${ }^{1230}$ Yet this argument is only relevant if the interpreter systematically focuses on the text's ordinary meaning in priority or to the exclusion of other interpretative methods. ${ }^{1231}$ Such a one-sided approach does not respect the interpretative methods of international law, and it would be a mistake to conflate textual interpretation and textualism (supra,

1228 This is suggested by Allott's description of treaties as 'disagreement[s] reduced to writing': Allott (n 1107) 43.

1229 Eg Stanley Fish, 'Response: Interpretation Is Not a Theoretical Issue' (1999) 11 Yale Journal of Law and the Humanities 509, $510 \mathrm{f}$.

1230 Andrea Bianchi, 'Textual Interpretation and (International) Law Reading: The Myth of (In)Determinacy and the Genealogy of Meaning' in Pieter HF Bekker, Rudolf Dolzer, and Michael Waibel (eds), Making Transnational Law Work in the Global Economy: Essays in Honour of Detlev Vagts (Cambridge University Press 2010).

1231 For an example of such a textualist approach to treaty interpretation, see Andrew Tutt, 'Treaty Textualism' (2014) 39 Yale Journal of International Law 283. 
2.1). On this last point, criticizing the VCLT's allegedly 'textualist' flavor, ${ }^{1232}$ or considering that it commands textualism, ${ }^{1233}$ is misguided. The Convention was explicitly designed to allow for a flexible approach to interpretation based on different interpretative methods and, as Richard Gardiner notes, '[o]ne has to start somewhere.'1234

In short, it is fair to say that textual interpretation is pervasive, customary, and mandatory in international law.

\section{$2.2 \quad$ Systematic Interpretation}

2.2.1 Domestic Law

Savigny describes the 'systematic' (contextual) element as the 'inner linkage which connects all legal institutes and legal rules so as to form one unitary whole.' ${ }^{1235}$ Context, on his account, is limited to legal acts and institutions. It does not encompass elements such as the socio-cultural milieu in which interpretation occurs. Savigny's understanding of context presupposes that the law is a unitary, coherent ('systematic') whole, and not an aggregate of legal acts that can all be interpreted in isolation.

Systematic interpretation is a common interpretative method in all jurisdictions that have adopted Savigny's four methods. It is also used in common law countries. ${ }^{1236}$

Several reasons warrant looking at the law's context. First, if reading the text of the law is, intuitively, the first interpretative step, paying attention to its context is the second one. A legal provision is part of a broader regulatory scheme. Even unwritten laws do not exist in a vacuum. They belong to a pattern of

1232 See famously Myres S McDougal, 'The International Law Commission's Draft Articles Upon Interpretation: Textuality Redivivus' (1967) 61 American Journal of International Law 992.

1233 JG Merrills, 'Two Approaches to Treaty Interpretation' (1969) 4 Australian Year Book of International Law 55, 78; Martin Ris, 'Treaty Interpretation and ICJ Recourse to Travaux Préparatoires: Towards a Proposed Amendment of Articles 31 and 32 of the Vienna Convention on the Law of Treaties' (1991) 14 Boston College International and Comparative Law Review 111, 117.

1234 Gardiner (n 359) 181.

1235 von Savigny (n 761$) 214$.

1236 Scalia and Garner (n 1209). Another example is the 'golden rule' used in English law, see Grey v. Pearson (1857) 6 HL Cas 61, 106; 1OER 1216, 1234: 'in construing statutes, as well as in construing all other written instruments, the grammatical and ordinary sense of the words is to be adhered to, unless that would lead to some absurdity or inconsistence with the rest of the instrument, in which case the grammatical and ordinary sense of the words may be modified, so as to avoid that absurdity or inconsistency, but no further' (emphasis added). See also The Interpretation of Statutes (n 54) $7 \mathrm{f}$. 
rights and duties. Second, officials must abide by the law. If judges interpret a legal act in isolation, they might violate other legal norms. Such interpretations might also impose contradictory obligations on the law's subjects.

Systematic interpretation does not come without a series of criticisms. First, it may require judges to overstep their institutional powers. If the legislature adopts two contradictory laws (as it often does, whether deliberately or not), it is arguably not for judges to step in. However, this objection can be flipped by saying that good judicial reasoning mandates predictability, clarity and, importantly, consistency.

Second, one could object on the basis that coherence is not an end in itself, and that it may not always be warranted. ${ }^{1237}$ The need for coherence may be outweighed by other considerations, eg reliance interests or fundamental rights. Yet this objection neglects the fact that using context does not mean that context must necessarily and always prevail.

Third, one could object on the grounds that systematic interpretation is indeterminate. Should the interpretation of a given legal act cohere with the substantive area of the law to which it belongs? With the legal system as a whole? ${ }^{1238}$ However, the fact that the proper way of achieving systematicity is controversial only shows that systematic interpretation must be accompanied by a careful justification. It does not demonstrate that striving for systematicity (however we define it) is unwarranted perse.

Fourth, systematicity arguably imposes a disproportionate burden on judges. Law is messy, one could argue, and it may be impossible for courts to disentangle it to secure coherence. ${ }^{1239}$ Yet the practical difficulties of achieving coherence do not mean that coherence is not worth striving for.

To conclude, systematic interpretation is an established interpretative method in domestic law, and there are compelling reasons to call for its use.

\subsubsection{International Law}

Systematic (or contextual) interpretation matters on the international plane as well. Regarding treaty interpretation, art. 31(1) VCLT mandates contextual interpretation. Art. 31(2) VCLT specifies the notion of context, and art. 31(3) VCLT identifies elements to be 'taken into account, together with the context', ie, subsequent agreements (a), subsequent practice (b), and international law

1237 Joseph Raz, Ethics in the Public Domain: Essays in the Morality of Law and Politics (Clarendon Press 1994) ch 13. See also Dickson (n 78) para 3.3.

1238 On local versus global coherence, see Dickson (n 78 ) para 3.5.

1239 Under Swiss law, for instance, a popular vote can lead to the adoption of a constitutional norm that creates what seems like an irreconcilable tension with existing norms. 
applicable to the treaty parties (c). The circumstances surrounding the conclusion of the treaty are 'supplementary means of interpretation' (art. 32 VCLT). Systematic interpretation is also relevant to identify CIL. ${ }^{1240}$ It is required in order to examine if State practice is sufficiently coherent, constant, and gener$\mathrm{al}$, or when treaties are used to ascertain custom. The ILC's draft conclusions on custom mention context several times, ${ }^{1241}$ as does the ILA's project on CIL. ${ }^{1242}$ General principles of international law must also be interpreted in a contextual fashion. While general principles identified in foro domestico require that interpreters go beyond the purely domestic context in which a domestic practice has developed, as they need to establish whether this practice expresses a general principle of international law, ${ }^{1243}$ this domestic context cannot be ignored in the first place. ${ }^{1244}$ General principles of international law stricto sensu must also be identified by considering the context in which they have emerged.

Context is regularly mentioned by States and their courts when they interpret treaties, ${ }^{1245}$ although references to art. $31(2)$ and (3) VCLT are relatively rare. ${ }^{1246}$ Context is also prominent in the Harvard Draft Convention on the Law of Treaties. ${ }^{1247}$ The ILC has analyzed the principle of systemic integration $^{1248}$ in its report on the fragmentation of international law. ${ }^{1249}$ Moreover,

1240 d'Aspremont, 'The Systemic Integration of International Law by Domestic Courts: Domestic Judges as Architects of the Consistency of the International Legal Order' (n 1191) $15^{1} \mathrm{ff} ;$ Jean d'Aspremont, 'Articulating International Human Rights and International Humanitarian Law: Conciliatory Interpretation Under the Guise of Norms-Resolution' in Malgosia Fitzmaurice and Panos Merkouris (eds), The Interpretation and Application of the European Convention of Human Rights: Legal and Practical Implications (Martinus Nijhoff 2013). Contra Philippe Sands, 'Treaty, Custom, and the Cross-Fertilization of International Law' (1998) 1 Yale Journal of International Development Law 85, 94.

1241 Draft conclusions 3(1), 6(2), 7(1), and 10(2), ILC, 'Draft Conclusions on Identification of Customary International Law, With Commentaries' (n 891).

1242 ILA Committee on Formation of Customary (General) International Law (n 886) 17. See at 9: "The practice of the executive, legislative and judicial organs of the State is to be considered, according to the circumstances, as State practice'. See also at 21.

1243 Ellis (n 1203) $961 \mathrm{f}$.

1244 Jain (n 73) $137 \mathrm{ff}$.

1245 On the practice of English courts, see Fatima (n 45) $114 \mathrm{ff}$.

1246 For an example to the contrary regarding domestic courts' reliance on subsequent practice in treaty interpretation, see 'Article 19. Interpretation of Treaties' (n 121) 968.

1247 See art. 19(a), 'Harvard Draft Convention on the Law of Treaties' (n 1197).

1248 Art. 31(3)(c) vCLT.

1249 ILC, 'Fragmentation of International Law: Difficulties Arising From the Diversification and Fragmentation of International Law' (n 296) paras 410-48o. See also Anne van Aaken, 'Defragmentation of Public International Law Through Interpretation: A Methodological Proposal' (2009) 16 Indiana Journal of Global Legal Studies 483. 
in 2018, the ILC adopted a set of draft conclusions on subsequent agreements and subsequent practice. ${ }^{1250}$ Context is frequently mentioned in the case law of international courts. These courts refer to context both stricto sensu (as per art. 31(1) and (2) VCLT) and lato sensu (pursuant to art. 31(3) and art. 32 VCLT). ${ }^{1251}$ Scholars also stress the importance of the interpretative context. ${ }^{1252}$ States likewise mention context when ascertaining custom, though less frequently than in treaty interpretation. ${ }^{1253}$ Ireland for instance, when commenting on the ILC's work on CIL, stated that 'the weight which can be given to a particular statement varies greatly depending on the circumstances in which it was made. ${ }^{1254}$ Regarding the use of context to ascertain general principles of international law, domestic and international practice is scarce. In some cases, however, international courts have engaged in a comprehensive contextual survey of national practices by analyzing how an issue is addressed in different legal orders. ${ }^{1255}$

Why require States and their courts to use context when interpreting international law? The reasons echo those in domestic law. First, contextual

1250 ILC, 'Draft Conclusions on Subsequent Agreements and Subsequent Practice' (2018) UN Doc A/73/10 12 .

1251 See the references in Sorel and Boré-Eveno (n 1044) $817 \mathrm{ff}$. See also d'Aspremont, 'The Systemic Integration of International Law by Domestic Courts: Domestic Judges as Architects of the Consistency of the International Legal Order' (n 1191) $149 \mathrm{ff}$. Eg ICJ, case concerning Oil Platforms (Iran v. United States), judgment, merits, ICJ Reports 2003, 6 November 2003, 161, at 182, para 41; ICJ, case concerning the Legal Consequences for States of the Continuous Presence of South Africa in Namibia (South West Africa) Notwithstanding Security Council Resolution 276 (1970), advisory opinion, ICJ Reports 1971, 21 June 1971, 16, at 31 f, para 53. On the circumstances of the conclusion of the treaty, see ICJ, case concerning Legality of Use of Force (Serbia and Montenegro v. Belgium), judgment, preliminary objections, ICJ Reports 2004, 15 December 2004, 279 (see especially at 318, para 100, and at $323 \mathrm{f}$, para 113). Evolutive interpretation, which characterizes the case law of regional human rights courts, is allowed by art. 31(3)(b) vCLT. On this issue, see Daniel Moeckli and Nigel D White, 'Treaties as "Living Instruments"' in Dino Kritsiotis and Michael Bowman (eds), Conceptual and Contextual Perspectives on the Modern Law of Treaties (Cambridge University Press 2018).

1252 Bianchi (n 1230) $41 \mathrm{ff}$.

1253 For an example in the practice of English courts, see Fatima (n 45) 419.

1254 Ireland, <legal.un.org/docs/?path=../ilc/sessions/66/pdfs/english/icil_ireland. pdf\&lang=E $>$, at 2.

1255 See some of the examples regarding international criminal tribunals discussed by Fabián Raimondo, General Principles of Law in the Decisions of International Criminal Courts and Tribunals (Martinus Nijhoff 2008) $84 \mathrm{ff}$. The PCIJ and ICJ have not conducted such comparative surveys, however, see ibid $57 \mathrm{f}$. 
interpretation is a matter of 'both common sense and good faith.'1256 Several laws are applicable to a dispute, and courts must consider them all (provided, of course, that this is consistent with the court's jurisdiction and procedural law). Second, using context helps ensure that the law does not impose contradictory obligations on its addressees. The PCIJ for instance has linked the contextual element with the need to avoid 'unreasonable or absurd results'.1257 The ICJ has even considered that context, jointly with the text, takes precedence over other interpretative methods if it allows 'mak[ing] sense [of the relevant words].'1258 This stands in continuity with the PCIJ's statement that context helps limit the number of possible interpretations of a given text and is 'the final test' of ordinary meaning. ${ }^{1259}$

In international law, context excludes the acts of one State that have not been endorsed by a sufficient number of other States. ${ }^{1260}$ In 2014, the ICJ refused to apply art. 31(3)(a) and (b) vCLT to resolutions of the International Whaling Commission that had not been adopted with the support of all parties to the Whaling Convention. ${ }^{1261}$ Yet in its advisory opinion on Namibia, the ICJ invoked the practice of the Security Council to support its interpretation of

1256 ILC, 'Draft Articles on the Law of Treaties With Commentaries' (n 783) 221.

1257 PCIJ, case concerning the Polish Postal Service in Danzig (Poland v. High Commissioner of the League of Nations and Free City of Danzig), advisory opinion, PCIJ Series B No 11, 16 May 1925, 6, at 39 .

1258 ICJ, Competence of the General Assembly for the Admission of a State to the United Nations, advisory opinion, ICJ Reports 1950, 3 March 1950, 4, at 8. See also PCIJ, case concerning the Polish Postal Service in Danzig (Poland v. High Commissioner of the League of Nations and Free City of Danzig), advisory opinion, PCIJ Series B No 11, 16 May 1925, 6, at 39.

$1259 \mathrm{PCIJ}$, Competence of the ILO in Regard to International Regulation of the Conditions of the Labour of Persons Employed in Agriculture, advisory opinion, PCIJ Series B No 3, 12 August 1922,8 , at 23,35 .

1260 Regarding CIL, see the comments submitted by the United Kingdom, <legal.un.org/docs/ ?path=../ilc/sessions/66/pdfs/english/icil_uk.pdf\&lang=E>, at 44 (stating that 'it would be both inappropriate and undesirable for a domestic court to make a unilateral ruling, identifying a new rule of corporate liability based on customary international law'). See however Austria, <legal.un.org/docs/?path=../ilc/sessions/67/pdfs/english/icil_austria. pdf\&lang=E $>$, p. 20 (in favor of extending the scope of actors with the authority to contribute to the formation of CIL). For an example, see ICJ, case concerning Sovereignty Over Pulau Ligitan and Pulau Sipadan (Indonesia v. Malaysia), judgment, merits, ICJ Reports 2002, 17 December 2002, 625, at 650, para 47.

1261 ICJ, case concerning Whaling in the Antarctic (Australia v. Japan; New Zealand intervening), judgment, ICJ Reports 2014, 31 March 2014, 226, at 257, para 83. On this judgment, see d'Aspremont, 'The International Court of Justice, the Whales, and the Blurring of the Lines Between Sources and Interpretation' (n 224). 
the UN Charter, in spite of the abstention of some of the Council's permanent members. ${ }^{1262}$

Systematic interpretation has various drawbacks. First, one might argue that context, and especially the principle of systemic integration of art. 31(3)(c) VCLT, can require judges to overstep their powers. Given the decentralized creation of international law, there are likely to be tensions between States' various rights and duties. By considering subsequent agreements and subsequent practice, judges might depart from the lawmakers' original intentions. ${ }^{1263}$ This arguably clashes with their legal duty to obey the law. ${ }^{1264}$ Yet as previously mentioned (supra, 2.2.1), this argument can be flipped, since respecting all applicable legal acts is precisely what this duty requires from judges.

Second, one could contend that the systematicity of international law is a normative claim that needs to be argued for. ${ }^{1265}$ The same applies to the claim that judges should be 'architects of the consistency of the international legal order. ${ }^{1266}$ Yet this objection targets systematic interpretative theories (supra, Chapter 2, 5.1). Systematic interpretation is, per se, agnostic about whether international law is (or should be) a system or not.

Third, it can be argued that context, and the requirement that other related elements 'shall be taken into account'1267 in conjunction with it, leaves ample space for indeterminacy and, potentially, for judicial cherry-picking. This statement disregards the fact that context is conceptually distinct from the 'circumstances of [...] conclusion' of the treaty (art. 32 VCLT). Art. 31(3)(c) VCLT has for example been called the 'passe-partout' of international law. ${ }^{1268}$ However, its

1262 ICJ, case concerning the Legal Consequences for States of the Continuous Presence of South Africa in Namibia (South West Africa) Notwithstanding Security Council Resolution 276 (1970), advisory opinion, ICJ Reports 1971, 21 June 1971, 16, at 22, para 22.

1263 ICJ, case concerning Navigational and Related Rights (Costa Rica v. Nicaragua), judgment, merits, ICJ Reports 2009, 13 July 2009, 213, at 242, para 64.

1264 As previously mentioned, this duty is primarily domestic, but it can also be a corollary of States' international obligations.

1265 Peter Staubach, 'The Interpretation of Unwritten International Law by Domestic Judges' in Helmut Philipp Aust and Georg Nolte (eds), The Interpretation of International Law by Domestic Courts: Unity, Diversity, Convergence (Oxford University Press 2016) 120.

1266 d'Aspremont, 'The Systemic Integration of International Law by Domestic Courts: Domestic Judges as Architects of the Consistency of the International Legal Order' (n 1191).

1267 Art. 31(3) vCLT.

1268 Campbell McLachlan, 'The Principle of Systemic Integration and Article 31(3)(c) of the Vienna Convention' (2005) 54 International and Comparative Law Quarterly 279, $280-281$. 
wording does not allow courts to take any possible provision of international law into account.

Fourth, the inconsistencies that exist between a given international legal act and its context are sometimes irreconcilable. The difficulty this argument points at is not intrinsic to contextual interpretation, but is instead a result of the limitations of systematic normative theories.

In short, while contextual interpretation does not answer all interpretative questions, good reasons explain why States do and must interpret international law in its context.

\subsection{Teleological Interpretation \\ 2.3.1 Domestic Law}

Savigny defined the law's purpose as 'the effect that the law is intended to achieve.' ${ }^{269} \mathrm{He}$ considered that purposive interpretation ought to be conducted exceptionally and only 'with great caution.'.1270 Today, in civil law jurisdictions like Switzerland, purposive interpretation stands on a par with other interpretative methods. It is also used in common law jurisdictions. ${ }^{1271}$ Some domestic judges even endorse purposive interpretative theories. ${ }^{1272}$

Why require that interpreters use the purpose of a legal act to interpret it? First, purposive interpretation is a way of deferring to legislative choices. If the legislature demonstrably intended a given legal act to achieve purpose $\mathrm{X}$, interpreting this act by postulating that its purpose is $\mathrm{Y}$ disregards legislative intent. By the same token, by deferring to $X$, judicial decision-makers respect the law's intended purpose.

At the same time, purposive interpretation instils flexibility into the interpretative process without necessarily disregarding legislative intent. If the legislative purpose is defined at a sufficient level of generality, teleology allows taking new circumstances into account without departing from this legislative intent lato sensu. ${ }^{1273}$

\footnotetext{
1269 von Savigny (n 761) 217.

1270 See ibid 220.

1271 In the United Kingdom, for instance, the mischief rule of statutory interpretation requires that judges identify the 'mischief' that led to the enactment of a given piece of legislation in order to 'cure' it. See The Interpretation of Statutes (n 54) 14.

1272 Aharon Barak, Purposive Interpretation in Law (Princeton University Press 2005).

1273 Some us scholars advocate reading the drafters' intentions at a higher level of generality, eg Lessig, 'Understanding Changed Readings: Fidelity and Theory' (n 831); Lessig, 'Translating Federalism: United States v Lopez' (n 831); Sunstein, 'Five Theses on Originalism' (n 831).
} 
Purposive interpretation is problematic in several respects. First, identifying the purpose of a legal act raises evidentiary difficulties. One challenge, in this context, is collective intentionality. What common objective did an aggregate of legislators aim for, if at all, and how can this objective be ascertained? The purpose of legal acts can be highly indeterminate, and its identification leaves ample room for disagreement. Second, in light of these evidentiary challenges, purposive interpretation can easily be criticized for being unconstrained. Given the indeterminacy of the purpose of a legal act, judges will likely be frowned upon for reading their own values in the law. One illustration of this challenge is the disagreement between Justice Chase and Justice Iredell in Calderv. Bull as to the weight that ought to be given to natural law arguments. ${ }^{1274}$

Yet the fact that purposive interpretation is not always straightforward and leaves space for interpretative discretion does not mean that it should be abandoned. Rather, teleology must be handled with care, and used jointly with other interpretative methods.

\subsubsection{International Law}

Purposive interpretation is also prominent in international law. It is the third method of treaty interpretation mentioned by art. 31(1) VCLT. While some authors argue that the 'object and purpose' of a treaty refer to two conceptually distinct features of the treaty, namely to its content and to the goal the parties wanted to achieve through it, ${ }^{1275}$ this distinction has not gained any clout in international legal practice. Another provision linked to teleology is art. 31(3)(b) VCLT, which allows resorting to subsequent treaty practice (and hence to changing circumstances). ${ }^{1276}$ Purposive interpretation is the first method mentioned in the 1935 Harvard Draft Convention on the Law of Treaties, where it is emphasized twice. ${ }^{1277}$ It is also relevant for the ascertainment of CIL. Although the ILC's draft conclusions do not mention the notion of 'purpose', they provide that when ascertaining CIL, 'regard must be had to the overall context, the nature of the rule, and the particular circumstances in which the evidence in question is to be found ${ }^{1278}$ (emphasis added). This leaves room for

1274 Calderv. Bull, 3 U.s. 386 (1798).

1275 Buffard and Zemanek (n 1154) 325-326. Contra Hervé Ascensio, 'Article 31 of the Vienna Conventions on the Law of Treaties and International Investment Law' (2016) 31 ICSID Review 366, 370.

1276 Fitzmaurice, 'The Law and Procedure of the International Court of Justice, 1951-4: Treaty Interpretation and Other Treaty Points' (n 1006) 210.

1277 Art. 19(a), 'Harvard Draft Convention on the Law of Treaties' (n 1197).

1278 Draft conclusion 3(1) in ILC, 'Draft Conclusions on Identification of Customary International Law, With Commentaries' (n 891). 
teleological considerations, ${ }^{1279}$ as the nature of an object cannot be defined without considering its purpose (and vice versa). The 'nature of the act' is also mentioned by the ILA as a relevant element to determine whether a given act belongs to comity, as opposed to being required by CIL. ${ }^{1280}$ Finally, purposive interpretation comes into play to identify general principles of international law. Scholars note that extracting a general principle from domestic practices requires reflecting upon the goal these practices aim at achieving. ${ }^{1281}$ Stephan Schill, who analyzes general principles of international investment law, argues that the purpose of a given substantive area of international law determines the material based on which such principles ought to be identified. ${ }^{1282}$ This is confirmed by Sir Arnold McNair's often quoted statement in the South-West Africa case that domestic legal concepts should not be 'directly import[ed]' into international law 'lock, stock and barrel' qua general principles of international law. Instead, features of international law that are reminiscent of domestic legal concepts should be taken 'as an indication of policy and principles'. ${ }^{283}$

The purposive element is particularly present in the practice of treaty interpretation. It is often mentioned in the Swiss case law on treaty law, for instance, ${ }^{1284}$ and by other domestic courts. ${ }^{1285}$ The Harvard Draft Convention on the Law of Treaties gives purposive interpretation a central place. ${ }^{1286}$ Teleology is also frequently used by international courts to interpret treaties. ${ }^{1287}$ It has for instance been relied upon by the PCIJ in the framework of the doctrine of implied powers of IOs, ${ }^{1288}$ and it is frequently invoked to interpret constitutive treaties of IOs. ${ }^{1289}$ It is also a common feature in the interpretation of

1279 See also Yves Le Bouthillier's argument pursuant to which the 'nature of the treaty', ie, the purpose for which it was concluded, is a circumstance of conclusion of the treaty as per art. 32 VCLT: Le Bouthillier (n 1185) 86o.

128 o ILA Committee on Formation of Customary (General) International Law (n 886) 35 .

1281 Ellis (n 1203) $959 \mathrm{ff}$.

1282 Schill (n 1204) 148.

1283 Separate opinion of Sir Arnold McNair in ICJ, case concerning the International Status of South-West Africa, advisory opinion, ICJ Reports 1950, 11 July 1950, 146, at 148.

1284 See the references in Besson and Ammann (n 97 ) $341 \mathrm{f}$.

1285 Fatima (n 45) 118 ff; Waibel, 'Principles of Treaty Interpretation: Developed for and Applied by National Courts?' (n 183) 23, 25 .

1286 'Article 19. Interpretation of Treaties' (n 121) 938.

1287 Sorel and Boré-Eveno (n 1044) $832 \mathrm{ff}$.

1288 Eg PCIJ, Competence of the ILO to Regulate, Incidentally, the Personal Work of the Employer, advisory opinion, PCIJ Series B No 13, 23 July 1926, 6, at 18.

1289 On this topic, see Denys Simon, L'interprétation judiciaire des traités d'organisations internationales: morphologie des conventions et fonction juridictionnelle (Pedone 1981); Brölmann (n 1205). 
international human rights treaties. ${ }^{1290}$ In this context, scholars underscore the 'visceral attachment' ${ }^{\prime 291}$ that some international courts, especially human rights courts such as the ECtHR ${ }^{1292}$ or the IACtHR, show to the teleological method. ${ }^{1293}$ States sometimes resort to purposive considerations to identify CIL. Purposive interpretation has for example been used by the BVerfG ${ }^{1294}$ and by Swiss courts to determine CIL. ${ }^{1295}$ Finally, teleology has been relied on with regard to general principles of international law, which must be ascertained based on the ratio legis of national laws and the specificities of international law. ${ }^{1296}$

Why use the object and purpose of international legal acts? First, this method is in line with judges' duty to obey the law. The ILC considers that purposive interpretation is required by 'both common sense and good faith,, ${ }^{1297}$ and Yves Le Bouthillier notes that it is often necessary to determine whether an interpretation leads to a 'manifestly absurd or ambiguous result' (art. 32 VCLT). ${ }^{1298}$ Judges who, through their interpretations, defeat the purpose of a legal act, disregard the law. A treaty that mandates the unification or harmonization of an area of the law, ${ }^{1299}$ for instance, cannot be interpreted like an international human rights treaty governed by the principle of subsidiarity, as the respective purposes of these instruments differ. Second, purposive interpretation leaves room for evolutionary interpretation (even if there is no necessary connection between them). Through teleology, judges can take evolving social needs and circumstances into account without being straightjacketed by the text's

1290 Some authors advocate applying the 'living instrument' metaphor beyond IHRL, eg Moeckli and White (n 1251).

1291 Sorel and Boré-Eveno (n 1044) 833.

1292 Eg ECtHR, Al-Saadoon and Mufdhi v. United Kingdom, App No 61498/o8 (ECHR Reports 2010), 2 March 2010, at para 127.

1293 See also ICJ, case concerning Reservations to the Convention on the Prevention and Punishment of the Crime of Genocide, advisory opinion, ICJ Reports 1951, 28 May 1951, 15 , at $23 \mathrm{f}$.

1294 Staubach (n 1265) $120 \mathrm{f}$.

1295 BGer, judgment 1A.63/2002 of 9 April 2002, at 2.1.

1296 ICTy (Trial Chamber II ), Prosecutorv. Anto Furundžija, judgment, Case No IT-95-1 7/ 1-T, 10 December 1998, para 178. See also the separate and dissenting opinion of Judge Stephen in ICтY (Appeals Chamber), Prosecutor v. Dražen Erdemović, judgment, Case No IT-96-22-A, 7 October 1997, para 63.

1297 ILC, 'Draft Articles on the Law of Treaties With Commentaries' (n 783) 221.

1298 Le Bouthillier (n 1185) 850.

1299 Eg the Convention for the Unification of Certain Rules Relating to International Carriage by Air of 12 October 1929, or the UN Convention on Contracts for the International Sale of Goods of 11 April 1980. 
original textual meaning (although teleology can also be an argument for sticking to the originally envisaged purpose).

Purposive interpretation can be criticized in various respects. One weighty difficulty is the indeterminacy that often surrounds the 'enigmatic'1300 notion of object and purpose, as many authors note in the context of the VCLT. ${ }^{1301}$ The overall object and purpose of a treaty can be in tension with that of specific provisions. Moreover, a treaty often pursues several goals. ${ }^{1302}$ Consequently, the way the object and purpose are interpreted is likely to be influenced by the personal views of the judicial decision-maker. The same point has been made about purposive interpretation to ascertain general principles of international law. ${ }^{1303}$ This objection must be taken seriously: purposive interpretation must, indeed, be used with caution, and it cannot, on its own, form the basis of a judicial decision. ${ }^{1304}$ This does not mean that teleology should be discarded altogether. Rather, judges must demonstrate that States did actually pursue a given object and purpose, ie, that teleology can be (and is) determinate.

Second, purposive interpretation is often criticized for disregarding the parties' original intent. ${ }^{1305}$ The ECtHR for instance considers that purposive interpretation justifies that the text of the ECHR should not be interpreted in an originalist fashion, ie, based on the parties' original intent. ${ }^{1306}$ This position is often met with skepticism on the part of States. However, purposive interpretation does not require purposivism. Moreover, the ECtHR's rationale for interpreting the European Convention in an evolutionary way is often mischaracterized. Evolutionary interpretation is, in most cases, warranted because of the socalled 'European consensus' that has formed on a given issue. Hence, it is not disconnected from States' (present) intentions, nor from States' past intentions to protect individual rights (unless this past intention is defined very narrowly). Both originalism and purposivism are normative interpretative theories that

1300 Buffard and Zemanek (n 1154).

1301 Jan Klabbers, 'Some Problems Regarding the Object and Purpose of Treaties' (1997) 8 Finnish Yearbook of International Law 138. See the eight different uses of 'object and purpose' highlighted by David S Jonas and Thomas N Saunders, 'The Object and Purpose of a Treaty: Three Interpretive Methods' (2010) 43 Vanderbilt Journal of Transnational Law 565 .

1302 For an example, see ICJ, case concerning Kasikili/Sedudu Island (Botswana v. Namibia), judgment, merits, ICJ Reports 1999, 13 December 1999, 1045, at 1074, para 45.

1303 Ellis (n 1203) $959 \mathrm{f}$.

1304 For a similar argument, see Besson and Ammann (n 97) 349.

1305 Fitzmaurice, 'The Law and Procedure of the International Court of Justice, 1951-4: Treaty Interpretation and Other Treaty Points' (n 1006) 204, $207 \mathrm{f}$.

1306 On the ECtHR's approach to interpretation, see for example Letsas (n 79) $58 \mathrm{ff}$. 
must be argued for. Neither of them, per se, precludes resorting to purposive interpretation.

To summarize, there are good reasons for considering that purposive interpretation is a customary and good interpretative method in international law, even if its advantages should not blind judicial decision-makers to its limitations.

\section{$2.4 \quad$ Historical Interpretation \\ 2.4.1 Domestic Law}

Savigny defines historical interpretation as the reliance on the circumstances prevailing at the time a given law came into effect. ${ }^{1307}$ Based on Savigny's work, some continental legal systems, such as the Swiss or the German legal system, distinguish between objective and subjective historical interpretation. ${ }^{1308}$ The distinction roughly mirrors that between textualism and intentionalism in US constitutional law. In common law jurisdictions as well, historical interpretation is a well-known (though, in some States, debated) interpretative method. In the United States, originalism (and more specifically one of its subtypes, intentionalism $)^{1309}$ is a prominent interpretative theory. English courts accept the potential relevance of legislative history in ascertaining statutory law, but did not allow it before 1992. ${ }^{1310}$ The conditions for using this method remain controversial. ${ }^{1311}$ While most jurisdictions consider that recourse to preparatory work may be permissible, they diverge on the conditions of its use. ${ }^{1312}$

The main reason why judges should - at least in some circumstances - consult legislative history is that their duty to obey the law is arguably best served if they respect legislative intent. Using legislative history is an effective way of doing so.

On the other hand, the historical method is vulnerable to a number of criticisms. First, it raises evidentiary difficulties. Assuming that a reasonably homogeneous legislative intent even exists, there are different ways of ascertaining and assessing historical evidence. ${ }^{1313}$ Yet the fact that appraising this type of

1307 von Savigny (n 761) 214.

1308 Fleischer (n 156) $404 \mathrm{ff}$.

1309 Originalism is an umbrella term that includes textualism and intentionalism. See Letsas (n 79) 6o.

1310 Pepper (Inspector of Taxes) v. Hart [1992] UKHL 3, AC 593.

1311 On this issue, see The Interpretation of Statutes (n 54) 31 ff. See also Fleischer (n 156).

1312 Noting the disparity of domestic case law in this regard: 'Article 19. Interpretation of Treaties' (n 121) 958.

1313 Vermeule $\left(\mathrm{n}_{7} 6\right) 129 \mathrm{f}$. 
evidence is difficult does not mean that legislative history should simply be ignored. ${ }^{1314}$ It only means that judges must appraise it carefully.

Second, history is irrelevant when it gives no insight into the actual reasons that led the legislature to adopt a law. The English and Scottish Law Commissions have noted that legislative history is potentially unreliable because legislators, when debating a bill, primarily aim at persuading their audience. ${ }^{1315}$ This difficulty is not exclusive to historical interpretation, however. The text too can be a skewed reflection of legislative intent. Again, the objection only leads us to recognize that judges must appraise historical evidence carefully, and that they must also rely on other methods.

Third, resorting to legislative history is arguably undemocratic, since preparatory work has not been validated by the legislative process. This objection explains why judges like Antonin Scalia reject such extraneous, non-textual evidence. ${ }^{1316}$ Relatedly, one could argue that courts, by using legislative history, encroach upon the competences of the legislature. ${ }^{1317}$ Yet these critiques can be flipped, as refusing to look into legislative history can lead to a departure from what was democratically decided. An inquiry into the law's ordinary meaning at the time of its enactment that ignores legislative intent (as advocated by textualists such as Scalia) might fail to yield a clear-cut solution. ${ }^{1318} \mathrm{In}$ such cases, legislative history may bring clarity.

In short, there are good reasons for relying on legislative history when interpreting domestic law (at least in some cases), and this method is used in many jurisdictions.

\subsubsection{International Law}

Historical interpretation exists in international law as well. As regards treaty interpretation, art. 32 VCLT, entitled 'supplementary means of interpretation', provides that the travaux préparatoires ${ }^{1319}$ may be used to confirm a specific interpretation (a), or to avoid manifestly absurd or ambiguous results (b). This last point resembles the 'golden rule' in English statutory interpretation. The

\footnotetext{
1314 'Article 19. Interpretation of Treaties' (n 121) 958.

1315 The Interpretation of Statutes (n 54) $32 \mathrm{f}$.

1316 Fleischer (n 156) $424 \mathrm{f}$.

1317 Pepper (Inspector of Taxes) $v$. Hart [1992] UKHL 3, AC 593, at $606 \mathrm{f}$.

1318 According to Lord Denning, precluding judges from using legislative history is tantamount to saying that judges 'should grope about in the dark for the meaning of an Act without switching on the light'. See Davis v. Johnson [1979] AC 264, at 276.

1319 The circumstances of the conclusion of the treaty, which are also mentioned in art. 32 VCLT, form part of the context lato sensu (supra, 2.2.2).
} 
ILC abstained from defining the travaux, as it considered that such a definition would be underinclusive. ${ }^{1320}$ Importantly, the travaux must be public ${ }^{1321}$ and reflect the parties' common intentions, not an isolated position ${ }^{1322}$ or one that was subsequently abandoned. ${ }^{1323}$ Many courts (including the ICJ) ${ }^{1324}$ do not rigorously respect these conditions, however. One difficulty in this context is that CIL is not enacted through an institutionalized deliberative process like treaties. ${ }^{1325}$ Instead, it emerges based on State practice and opinio juris. Yet acts providing evidence of these two constitutive elements are analogous to the travaux, as they shed light on the process by which a custom has emerged. The material that can be considered for this purpose is defined in the ILC's draft conclusions 6(2) and $10(2) \cdot{ }^{1326}$ Similar lists are found in the ILA Resolution of 2000.1327 Evidence that only documents the practice and opinio juris of one (or few) States is, of course, insufficient. The requirement of publicity applies to these acts as well. ${ }^{1328}$ Historical interpretation is also relevant to ascertain general principles of international law. General principles identified in foro domestico are determined based on domestic practices. This requires an understanding of how these practices have emerged..$^{1329}$

The practice suggests that historical interpretation is, indeed, a customary interpretative method in international law. Hersch Lauterpacht noted in 1934

1320 ILC, 'Draft Articles on the Law of Treaties With Commentaries' (n 783 ) 223.

1321 See ibid. See also PCIJ, case concerning the Competence of the European Commission of the Danube Between Galatz and Braïla, advisory opinion, PCIJ Series B No 14, 8 December 1927,6 , at 32 .

1322 See for example ICJ, Ambatielos Case (Greece v. United Kingdom), judgment, preliminary objection, ICJ Reports 1952, 1 July 1951, 28, at 45 .

1323 See the examples mentioned by Hersch Lauterpacht, 'Les travaux préparatoires et l'interprétation des traités' (1934) 48 Recueil des cours de l'Académie de droit international 799 ff. See also Ris (n 1233) 112-113.

1324 See Ris (n 1233) 133.

1325 As a matter of fact, some scholars have criticized the imbalances that this unorderly process generates. See eg Chimni (n 1193).

1326 For a critique of the forms of State practice admitted by the ILC's draft conclusions on CIL: Sienho (n 960) $385 \mathrm{f}$.

1327 ILA Committee on Formation of Customary (General) International Law (n 886) 13 ff.

1328 Art. 24 ILC Statute reads: 'The Commission shall consider ways and means for making the evidence of customary international law more readily available [...]'. See also ILC, 'Fourth Report on Identification of Customary International Law by Michael Wood, Special Rapporteur' (n 294) 13 ff para 38 ff; ILC Secretariat, 'Identification of Customary International Law: Ways of Making the Evidence of Customary International Law More Readily Available' (2019) UN Doc A/CN.4/710/Rev.1.

1329 Drawing on the methods of comparative law: Ellis (n 1203) 962. See also Jain (n 73) $137 \mathrm{ff}$. 
that while States diverged in their approach to the travaux in the context of contractual and statutory interpretation, ${ }^{1330}$ they converged in accepting that the travaux could be used to interpret treaties. ${ }^{1331}$ While this method is the most controversial of all four methods when it comes to the conditions of its application, including in international law, ${ }^{1332}$ States have frequently relied on preparatory work for the purposes of treaty interpretation. ${ }^{1333}$ This practice is also reflected in the Harvard Draft Convention on the Law of Treaties of 1935, pursuant to which interpreters ought to consider 'the historical background of the treaty [and] travaux préparatoires.' ${ }^{1334}$ International courts have likewise relied on the travaux, ${ }^{1335}$ as have arbitral tribunals. ${ }^{1336}$ Jan Klabbers notes that 'most international lawyers will almost automatically include a discussion of preparatory works in legal argument, and will consider it vital to do so.'1337 States also rely on historical interpretation to ascertain CIL, ${ }^{1338}$ namely when they identify State practice and opinio juris. ${ }^{1339} \mathrm{Re}-$ garding general principles of international law, courts must establish that States have recognized a general principle for a sufficient period of time. Occasionally, they have hence examined the origins and development of these principles. ${ }^{1340}$

1330 Lauterpacht, 'Les travaux préparatoires et l'interprétation des traités' (n 1323) 733.

1331 See ibid 743 .

1332 Lauterpacht, 'Restrictive Interpretation and the Principle of Effectiveness in the Interpretation of Treaties' (n 248) 55 .

1333 Fatima (n 45) $131 \mathrm{ff}$.

1334 Art. 19(a). See 'Harvard Draft Convention on the Law of Treaties' (n 1197).

1335 Le Bouthillier (n 1185) 845; 'Article 19. Interpretation of Treaties' (n 121) 962 ff.

1336 Eg 'Article 19. Interpretation of Treaties' (n 121) $959 \mathrm{ff}$.

1337 Klabbers, 'International Legal Histories: The Declining Importance of Travaux Préparatoires in Treaty Interpretation?' (n 994) 268. For an empirical assessment, see Yahli Shereshevsky and Tom Noah, 'Does Exposure to Preparatory Work Affect Treaty Interpretation? An Experimental Study on International Law Students and Experts' (2017) 28 European Journal of International Law 1287.

1338 Regarding the practice of us and English courts: 'Article 19. Interpretation of Treaties' (n 121 ) 965 .

1339 ILC, 'Third Report on Identification of Customary International Law by Michael Wood, Special Rapporteur' (n 294) $21 \mathrm{ff}$.

1340 Italia Nostra v. Ministry of Cultural Heritage and Libyan Arab Jamahiriya (Intervening), Appeal Judgment, Case No 3154/2008, ILDC 1138 (IT 2008), 23 June 2008, Italy; Council of State [Council of State], at 4.4; Kiobel and Others (on Behalf of Kiobel and Tusima) v. Royal Dutch Petroleum Co and Others, Appeal judgment, Docket No o6-48oo-cv, Docket No o6-4876-cv, 623 F3d 111 (2d Cir 2010), ILDC $155^{2}$ (US 2010), 17 September 2010, United States; Court of Appeals (2nd Circuit) [2d Cir], at 43. 
In domestic law, ${ }^{1341}$ the historical approach usually ${ }^{1342}$ stands on equal footing with other canons, but its use is sometimes assorted with caveats. In international law, the historical method can only be used if specific conditions are fulfilled. As regards treaty interpretation, art. 32 VCLT provides that the travaux are merely 'supplementary means of interpretation'. This supplementary character had been stressed by international courts before the adoption of the VCLT ${ }^{1343}$ but the point was controversial in the drafting process of the Convention. ${ }^{1344}$ The hierarchy between art. 31 and art. $3^{2}$ VCLT clashes with the phenomenology of judicial decision-making, ${ }^{1345}$ and this hierarchy is often blurred in practice. The ICJ and PCIJ have often used preparatory work even when the conditions of art. 32 VCLT were not fulfilled. ${ }^{1346}$ The ECtHR

1341 Hersch Lauterpacht considered that international law needed to establish 'its own rules' on this issue: Lauterpacht, 'Les travaux préparatoires et l'interprétation des traités' (n 1323) 78 o.

1342 See however Stéphane Beaulac, 'No More International Treaty Interpretation in Canada's Statutory Interpretation: A Question of Access to Domestic Travaux Préparatoires' in Stéphane Beaulac and Mathieu Devinat (eds), Interpretatio non cessat: Mélanges en l'honneur de Pierre-André Côté / Essays in Honour of Pierre-André Côté (Yvon Blais 2011 ).

1343 ECtHR, Lawless v. Ireland (No 3), judgment, merits, App No 332/57 (ECHR Reports Series A No 3), 1 July 1961, para 14.

1344 Some States, such as Israel, Hungary, and the United States, considered that art. 32 VCLT ought to be on the same level as the methods of art. 31. See Sorel and Boré-Eveno (n 1044) 814. Documents like the Harvard Draft Convention on the Law of Treaties give the travaux a more prominent role, see art. 19(a), 'Harvard Draft Convention on the Law of Treaties' (n 1197).

1345 Merrills (n 1233) 61; Le Bouthillier (n 1185) 847.

1346 ICJ, case concerning Maritime Dispute (Peru v. Chile), ICJ Reports 2014, 27 January 2014, 4, at 30, para 66; ICJ, case concerning Sovereignty Over Pulau Ligitan and Pulau Sipadan (Indonesia v. Malaysia), judgment, merits, ICJ Reports 2002, 17 December 2002, 625, at $653 \mathrm{ff}$, para 53-58; ICJ, case concerning Avena and Other Mexican Nationals (Mexico v. United States), judgment, ICJ Reports 2004, 31 March 2004, 12, at $48 \mathrm{f}$, para 86. Contra (although the Court's reasoning is not explicit on this issue): ICJ, case concerning the Application of the Convention on the Prevention and Punishment of the Crime of Genocide (Bosnia and Herzegovina v. Serbia and Montenegro), judgment, ICJ Reports 2007, 26 February 2007, 43, at $109 \mathrm{ff}$, para 160-165; ICJ, case concerning the Legal Consequences of the Construction of a Wall in the Occupied Palestinian Territory, advisory opinion, ICJ Reports 2004, 9 July 2004, 136, at 174 ff, para 94-101. See also PCIJ, case concerning Article 3, Paragraph 2, of the Treaty of Lausanne (Frontier Between Turkey and Iraq), advisory opinion, PCIJ Series B No 12, 21 November 1925, 6, at 22 f; PCIJ, case concerning the s.s. 'Lotus' (France v. Turkey), judgment, PCIJ 1927 Series A No 10, 7 September 1927, 4, at $16 \mathrm{f}$; ICJ, Ambatielos Case (Greece v. United Kingdom), judgment, preliminary objection, ICJ Reports 1952, 1 July 1951, 28, at 45. 
has not been perfectly consistent in its practice either. ${ }^{1347}$ Some States have also stressed the supplementary character of historical interpretation in the context of CIL. ${ }^{1348}$

There are compelling reasons for resorting to historical interpretation in international law, at least in some cases, as this method is arguably a way of deferring to the lawmaking States. By taking into account how an international legal norm has come about, interpreters respect its sources and, therefore, States qua primary lawmakers.

However, like in domestic law, the historical method has raised criticism in international law (and this partly explains its supplementary role). First, historical interpretation can be challenged for being indeterminate. Ascertaining the intentions of an aggregate of States poses significant evidentiary difficulties. Moreover, there are different methods of ascertaining legislative history, depending on whether one defends an objective or a subjective approach to legislative history. ${ }^{1349}$ This indeterminacy creates the risk that the travaux will be invoked opportunistically. Some domestic courts hence only consider preparatory work deemed unequivocal. In Lord Steyn's words, '[o]nly a bull's eye counts. Nothing less will do.'.1350 The problem of indeterminacy also exists in CIL, given the range of materials that can provide evidence of State practice and opinio juris. Yet this objection - and the caution required in appraising the travaux - does not mean that historical interpretation is always indeterminate or misguided, and that it should not be taken seriously.

Second, legislative history (when it is available at all) ${ }^{1351}$ can be irrelevant. The records of treaty negotiations, for instance, may be inaccurate or incomplete. ${ }^{1352}$ They may not include 'last-minute negotiations, early in the morning after a sleepless night'.1353 The ILC also affirmed that the travaux were often 'incomplete and misleading', which justified according them a supplementary

1347 ECtHR, Witold Litwa v. Poland, judgment, merits, App No 26629/95 (ECHR Reports 20ooIII), 4 April 200o, at para 33-39, where the Court mentioned the travaux in the context of the applicable law.

1348 Ireland, <legal.un.org/docs/?path=../ilc/sessions/66/pdfs/english/icil_ireland. pdf\&lang=E $>$, p. 4 .

1349 Olivier Corten has demonstrated that the VCLT leaves room for either of these approaches, see Corten (n 247).

$135^{\circ}$ Effort Shipping Co. Ltd. v. Linden Management sA (1998) AC 605, 623.

1351 Klabbers, 'International Legal Histories: The Declining Importance of Travaux Préparatoires in Treaty Interpretation?' (n 994) 28o.

1352 Ris (n 1233) 113.

1353 Le Bouthillier ( $\mathrm{n} 1185) 857$. 
character. ${ }^{1354}$ As regards CIL, the positions adopted by States in the framework of IOs may be motivated by strategic considerations, and hence not be relevant for the purposes of ascertaining opinio juris. ${ }^{1355}$ Yet this objection only points to the evidentiary challenges raised by historical interpretation. It does not demonstrate that historical interpretation should be abandoned.

Third, resorting to the travaux is arguably misguided because no agreement has yet been reached at the negotiations and drafting stage. ${ }^{1356}$ Le Bouthillier notes that the travaux were given a supplementary role in the VCLT to avoid strategic conduct by the parties. Otherwise, States might have been tempted to strengthen their position in the event of future interpretative disputes by ensuring that their own view was included in the travaux. ${ }^{1357}$ However, the point of resorting to legislative history is precisely to identify what led to the enactment of a given law. While not all considerations made in this context are relevant, a fair amount of them yield insights into the process by which a provision was adopted.

Fourth, a common criticism is that the use of legislative history neglects that some States who became parties to the agreement at a later stage did not participate in the drafting process. This criticism should be taken seriously. It partly justifies why historical interpretation can only supplement other methods, pursuant to art. 32 vCLT. On the other hand, States that become parties at a later stage must be aware of the considerations underlying the agreement that is at stake. While they can - and should - contribute to shaping future interpretations of the treaty, they must acknowledge past interpretative choices of their treaty partners.

To conclude, historical interpretation is a customary method in international law, and rightly so, even if it must be used with caution.

\subsection{The Relationship between the Various Interpretative Methods}

In the previous subsections (2.1-2.4), I have focused on four interpretative methods of international law, ie, the textual, systematic, purposive, and historical method. I have analyzed whether these methods are indeed used in practice. I have also examined whether there are good reasons for using them.

1354 ILC, 'Draft Articles on the Law of Treaties With Commentaries' (n 783) 220.

1355 On this point, see Stephen Mathias, 'Editorial Comment - The Work of the International Law Commission on Identification of Customary International Law: A View From the Perspective of the Office of Legal Affairs' (2016) 15 Chicago Journal of International Law 17,25 .

1356 ILC, 'Draft Articles on the Law of Treaties With Commentaries' (n 783) 220.

1357 Le Bouthillier (n 1185) $858 \mathrm{f}$. 
It is fair to say that all of them are customary, and that every method has its virtues and its vices.

Interpretative methods are not a panacea: while they do contribute to the legality and quality of judicial decision-making, they do not guarantee it (supra, Chapter 5). ${ }^{1358}$ Jean-Marc Sorel and Valérie Boré-Eveno close their analysis of art. 31 VCLT by stating:

The absence of hierarchy between the different means of interpretation, their malleability, and the multiple ways of combining them, leave the door open to countless variations in this complex operation that constitutes treaty interpretation. Interpretation and legal integrity therefore at times seem antonymic, so great is the freedom left to interpreters who are left ample room to demonstrate creativity in their handling of texts. ${ }^{1359}$

The fact that no method guarantees legal and predictable, clear, and consistent judicial decisions does not mean that we should discard these methods. States (including courts) must use them, and for good reasons. On the other hand, all methods have drawbacks. Hence, the various methods must be used jointly, not in isolation, both in domestic and in international law.

This finding accords with domestic and international practice and scholarship. In domestic law, Friedrich Karl von Savigny states that decision-makers must use all four interpretative methods, although in some cases, it seems superfluous to explicitly mention them all. ${ }^{1360}$ The fact that all methods must be used is also stressed by the Swiss Federal Tribunal. ${ }^{1361}$ Similarly, in international law, one of the arbitrators' findings in the Lake Lanoux case was that international law 'consecrates no absolute and rigid system of interpretation. ${ }^{1362}$ In treaty law, for instance, the ILC deems the VCLT a 'crucible' in which all methods of the Convention are 'thrown [...], and their interaction [will] give the legally relevant interpretation.'.1363 Regarding CIL, the ILC's draft conclusions

1358 Lauterpacht, 'Restrictive Interpretation and the Principle of Effectiveness in the Interpretation of Treaties' (n 248) 53 .

1359 Sorel and Boré-Eveno (n 1044) 836 .

1360 von Savigny $\left(\mathrm{n}_{7} 61\right) 215$.

1361 BGE 142 V 442, at 5.1.

1362 Translated from French. See case concerning Lake Lanoux (Spain, France), award of 16 November 1957, Recueil des sentences arbitrales des Nations Unies, Vol XII, 281-317, at $301,2$.

1363 ILC, 'Draft Articles on the Law of Treaties With Commentaries' (n 783) 220. 
provide that State practice and opinio juris must be ascertained carefully and holistically, based on various pieces of evidence. ${ }^{1364}$ The AALCO stresses that custom must be identified 'based on a rigorous and systematic approach'.1365 Similar remarks apply to general principles of international law.

The Swiss Federal Tribunal's 'pragmatic methodological pluralism' (supra, Chapter 3, 4.2.6) conforms to these requirements to the extent the Court analyzes a case exhaustively, based on all interpretative methods. However, it does not if the Court chooses its methods 'à la carte,'1366 and if its decisions only reflect one part of the argumentative picture..$^{1367}$

In this chapter, I have argued that textual, systematic, teleological, and historical interpretation are common (and, arguably, customary) interpretative methods in both domestic and international law. They apply to all sources of international law, ie, treaty law, CIL, and general principles of international law. Specific adjustments may be required depending (inter alia) on the source at hand, and especially depending on the subject matter at stake.

Interpretative methods contribute to the legality of judicial interpretations of international law. They also reinforce their quality. Whether methods succeed in meeting these two goals ultimately depends on the way they are used by judges. The legality and quality of judicial reasoning are two aspects that often overlap and influence one another. While a predictable, clear, and consistent approach to interpretative methods strengthens the quality of a judicial decision and is more likely to secure its conformity with the sources of international law, an unpredictable, unclear, and inconsistent one opens the door to bad judicial reasoning and, potentially, to a disregard for the law.

In the remaining chapters, I examine how Swiss courts interpret acts stemming from various sources of international law. Chapter 7 is devoted to treaty interpretation. Chapter 8 concerns CIL and general principles of international

1364 See especially draft conclusions 3, 6, 7, and 10, ILC, 'Draft Conclusions on Identification of Customary International Law, With Commentaries' (n 891).

1365 Sienho (n 960) 382. See also, concurring: Wood (n 14) 9 .

1366 Gardiner (n 359) 147.

${ }_{1367}$ For an example, see Marc-André Renold, 'An Important Swiss Decision Relating to the International Transfer of Cultural Goods: The Swiss Supreme Court's Decision on the Giant Antique Mogul Gold Coins' (2006) 13 International Journal of Cultural Property 361,368 . 
law. In the conclusion, I summarize the findings of this study, and I suggest how the practice can be improved.

By focusing on the sources of international law, my analysis can be criticized for neglecting other angles that determine how international law must be (and is) interpreted. Such angles ${ }^{1368}$ include the law's addressees and beneficiaries, the institutional apparatus that monitors or reviews its interpretation and, perhaps most importantly, the substantive area at stake. ${ }^{369}$

While these angles must undoubtedly be taken into account to understand and evaluate the domestic judicial practice of international law, such a comprehensive study is beyond the scope of this book. Although it goes without saying that States (and, therefore, their courts) must respect the idiosyncratic interpretative State practice that has developed on the international plane with regard to specific substantive regimes of international law, an in-depth analysis of these interpretative peculiarities would require a significant expansion of the scope of my study. My aim is not to provide a textbook-like overview of the Swiss judicial practice, nor is it to offer a comprehensive account of this practice based on the various acts courts routinely interpret and the regimes these acts belong to. Instead, I evaluate the legality and quality of the Swiss judicial practice overall.

Finally, it is important to reiterate that I am not developing a general theory of the legitimacy of international law, of domestic law, or of Swiss judges' interpretations thereof (see also supra, Introduction, section 3). However, some of the normative propositions I defend in this study can be elements of a good theory of legitimacy. Indeed, I do defend views as to how judges must decide cases. I analyze the methods Swiss judges use to interpret treaties, CIL, and general principles of international law, and I evaluate the extent to which this practice conforms to the interpretative methods of international law and constitutes predictable, clear, and consistent reasoning.

1368 A range of relevant features can be found in Besson and Ammann (n 6o).

1369 On two important substantive areas in the Swiss judicial practice, namely the interpretation of the ECHR and the interpretation of the Swiss-EU Agreement on the Free Movement of Persons, see Odile Ammann, 'The European Court of Human Rights and Swiss Politics: How Does the Swiss Judge Fit In?' in Marlene Wind (ed), International Courts and Domestic Politics (Cambridge University Press 2018); Odile Ammann, 'La non-discrimination, principe charnière d'interprétation: l'exemple de l'art. 2 ALCP' in Samantha Besson and Andreas R Ziegler (eds), Egalité et non-discrimination en droit international et européen / Equality and Non-Discrimination in International and European Law (Schulthess 2014). 